\title{
Voltage Compensation for Solar Cell Array Comprising Multiple Strings
}

\author{
Hong-ren SHEN ${ }^{*}$ \\ Department of Electrical Engineering \\ National Kaohsiung University of Applied Sciences \\ Kaohsiung, Taiwan \\ e-mail: er650333@gmail.com \\ Hurng-liahng JOU \\ Department of Electrical Engineering \\ National Kaohsiung University of Applied Sciences \\ Kaohsiung, Taiwan \\ e-mail: hljou5519@gmail.com \\ Jinn-chang WU \\ Department of Microelectronics Engineering \\ National Kaohsiung Marine University \\ Kaohsiung, Taiwan \\ e-mail: jinnwu@mail.nkmu.edu.tw
}

\author{
Chang-lin TSAI \\ Department of Electrical Engineering \\ National Kaohsiung University of Applied Sciences \\ Kaohsiung, Taiwan \\ e-mail: andyabc5000@gmail.com
}

Kuen-der WU

Department of Electrical Engineering

National Kaohsiung University of Applied Sciences

Kaohsiung, Taiwan

e-mail: kuender@mail.ee.kuas.edu.tw

\author{
Cheng-huan CHUNG \\ Department of Electrical Engineering \\ National Kaohsiung University of Applied Sciences \\ Kaohsiung, Taiwan \\ e-mail: log203010@livemail.tw
}

\begin{abstract}
This paper proposes a voltage compensator (VC) for a grid-connected photovoltaic generation system to compensate shadowing phenomena. The solar cell array in this paper is composed of several strings using the same maximum power point. The proposed VC is an isolated DC-DC power converter which supplies a voltage to compensate for the voltage of shaded string in order to maintain the output voltages of every strings of a solar cell array to be the same. Therefore, the problem of multi-peaks in P-V curve of solar cell array caused by shadowing in a solar generation system can be solved. Therefore, the power generation in gridconnected photovoltaic generation system can be increased. A solar cell array comprising two strings is tested to verify the performance of the proposed VC. The experimental results are as expected.
\end{abstract}

Keywords- solar; voltage compensator; isolated DC-DC; shadowing

\section{INTRODUCTION}

The operating conditions and characteristics for each solar module in a solar cell array may be different. This is called as mismatch. Mismatch results in different output voltage and output current in each string of a solar cell array with several strings. Fortunately, the differences in the characteristics of solar modules in a string are generally small. However, the mismatch caused by cloud, the orientation of sun, or the shadow of buildings and trees, cannot be avoided in the practical applications [1-2]. The output current of a shaded solar cell is smaller than that of an un-shaded solar cell. This results in a reverse biased voltage in the shaded solar cell. Therefore, the shaded solar cell can be regarded as a load and it consumes real power. This may damage the shaded solar cells due to the hot spot on the shaded solar cells. For improving this problem, by-pass diode, connecting several solar cells in parallel, is including in a solar module and it conducts to by-pass the shaded solar cells [3-5]. However, by-pass diodes cannot solve all problems caused by shadowing.

The P-V (power-voltage) curves of solar modules depend on irradiance and temperature, and it has one unique maximum power point for different irradiance and different temperature [6-9]. Shadowing is an important phenomenon of mismatch, and it may result in the multi-peaks in P-V curve of solar cell array.

Maximum power point tracking (MPPT) is one of key technologies for the solar generation system [10-13]. To find the global maximum power point on a P-V curve with multiple-peaks of a solar cell array, many advanced MPPT methods [14, 15] have been proposed. However, the solar cell array does not output the true maximum output power even the global peak is tracked. Recently, power electronic compensators have been developed to solve the shadowing problems [16-19]. However, both the power circuit and the control circuit are complicated.

This paper focuses on a solar cell array composed of several strings using the same maximum power point tracker. A voltage compensator (VC) based on an isolated DC-DC converter is proposed for a grid-connected photovoltaic generation system. The proposed VC supplies a compensating voltage serially connected to a solar string with shaded modules to maintain the output voltage of the shaded string at almost the same level with the un-shaded strings in the same solar cell array using the same maximum 
power point tracker. Therefore, the problem of multiplepeaks in the P-V curve solar cell array caused by shadowing can be solved. A hardware prototype including a solar cell array comprising two strings is developed and tested to verify the performance of the proposed VC.

\section{CIRCUIT CONFIGURATION AND OPERATION THEORY}

Fig. 1 shows a grid-connected photovoltaic generation system including a solar cell array comprising two strings, a boost DC-DC converter and a grid-connected full-bride DCAC inverter and a DSP (TMDSDOCK28035) based controller. As can be seen, the solar cell array consists of two parallel connected strings, and each string has four solar modules. The function of boost DC-DC converter is to step up the output DC voltage and track the maximum output power of solar cell array, and the grid-connected full-bride DC-AC inverter is to stabilize the DC bus voltage, convert the DC power to AC power feeding into the utility.

The by-pass diodes in the solar module will be conducted if the shadowing occurs. This will result in the lower output voltage of shaded string in a solar cell array. The different output voltage of each solar modules string in a solar cell array may result in multi-peaks in the P-V curve of the solar cell array. It can be seen in Fig. 1 that the PV module 4 is shaded. The output voltage of the solar string with PV module 4 will be lower than other string if the by-pass diodes of PV module 4 are conducted. Therefore, the output current of the shaded string will also be lower than the un-shaded string. It may result in multi-peaks in the P-V curve of the solar cell array. This problem can be alleviated by inserting a DC voltage compensator in the shaded string to maintain the output voltage of the shaded string to be almost the same as the un-shaded string.

A voltage compensator (VC) based on an isolated DCDC power converter is adopted. The input voltage of this VC is the output voltage of solar cell array, and its output voltage is serially connected to a string of the solar cell array. This VC supplies a compensating voltage to maintain the output voltage of the shaded string at almost the same level with the un-shaded strings in the solar cell array using the same maximum power point tracker. The VC works while the currents of different solar strings are different. The setting

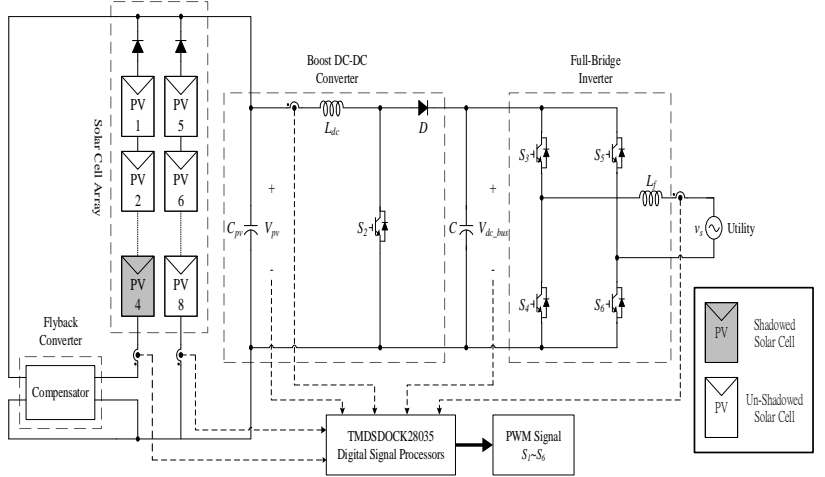

Figure 1. Grid-connected photovoltaic generation system including a solar cell array comprising two strings.

value for enabling VC is $0.1 \mathrm{~A}$. Therefore, this VC can improve the problem of multi-peaks in P-V curve caused by shadowing in a grid-connected photovoltaic generation system.

Fig. 2 shows the flowchart for controlling VC. The steps of the flowchart are shown as follows.

- $\quad$ Step 1: getting the currents of strings;

- $\quad$ Step 2: calculating the error of string currents;

- $\quad$ Step 3: (1) the error of string current is larger than the setting value, VC works and supplies the compensating voltage to maintain the voltages of strings to be almost the same;(2) the error of string current is smaller than the setting value, $\mathrm{VC}$ is disabled and back to step 1 ;

\section{EXPERIMENTAL RESULTS}

In order to verify the performance of the proposed compensation method, a prototype is developed and tested. The solar cell array is simulated by two solar simulators. Each simulator is used to simulate a string with four solar modules. Table 1 shows the parameters used in the solar simulator. The DC-DC power converter used in the prototype is a flyback power converter. The experimental results under three different conditions are shown in the follows. 


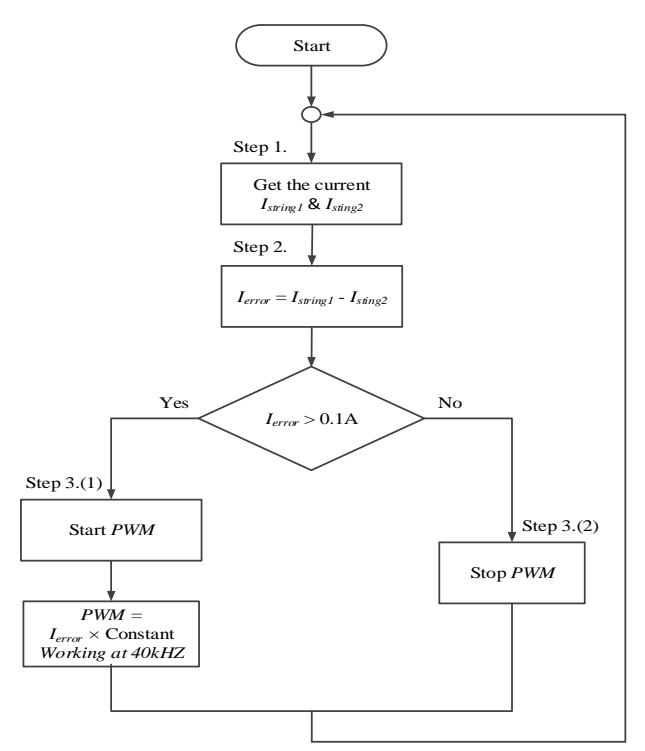

Figure 2. Flowchart for controlling VC.

TABLE I. PARAMETERS USED IN THE SOlAR SIMULATORS

\begin{tabular}{|l|l|l|l|}
\hline & $\begin{array}{c}\text { Un-shaded } \\
\text { solar } \\
\text { module }\end{array}$ & \multicolumn{2}{|c|}{$\begin{array}{c}\text { Shaded } \\
\text { solar module }\end{array}$} \\
\hline irradiance & $1000 \mathrm{~W} / m^{2}$ & $\begin{array}{l}300 \mathrm{~W} / \\
m^{2}\end{array}$ & $\begin{array}{l}100 \mathrm{~W} / \\
m^{2}\end{array}$ \\
\hline temperature & $50^{\circ} \mathrm{C}$ & $30^{\circ} \mathrm{C}$ & $30^{\circ} \mathrm{C}$ \\
\hline maximum power & $45.000 \mathrm{~W}$ & $\begin{array}{l}14.364 \\
\mathrm{~W}\end{array}$ & $\begin{array}{l}4.788 \\
\mathrm{~W}\end{array}$ \\
\hline $\begin{array}{l}\text { voltage at maximum } \\
\text { power }\end{array}$ & $30.000 \mathrm{~V}$ & $\begin{array}{l}26.357 \\
\mathrm{~V}\end{array}$ & $\begin{array}{l}21.280 \\
\mathrm{~V}\end{array}$ \\
\hline $\begin{array}{l}\text { current at maximum } \\
\text { power }\end{array}$ & $1.500 \mathrm{~A}$ & $0.545 \mathrm{~A}$ & $0.225 \mathrm{~A}$ \\
\hline open circuit voltage & $42.000 \mathrm{~V}$ & $\begin{array}{l}36.899 \\
\mathrm{~V}\end{array}$ & $\begin{array}{l}29.792 \\
\mathrm{~V}\end{array}$ \\
\hline short circuit current & $1.750 \mathrm{~A}$ & $0.636 \mathrm{~A}$ & $0.263 \mathrm{~A}$ \\
\hline
\end{tabular}

\section{A. Case 1}

Fig. 3 to 4 show the experimental results under the condition that all solar modules are un-shaded. The irradiance is $1000 \mathrm{~W} / \mathrm{m}^{2}$, and the temperature of the back panel is $50{ }^{\circ} \mathrm{C}$ in this case. Fig. 3 shows the I-V and P-V curves for string 1 and string 2 of the solar simulators. As seen in Fig. 3, The open circuit voltage, $V_{\text {oc }}$, of the each string is $168 \mathrm{~V}$, the short circuit current, $I_{\mathrm{sc}}$, of each string is $1.75 \mathrm{~A}$, the voltage at the maximum power point of each string is $123.8 \mathrm{~V}$, the current at the maximum power point, $I_{\mathrm{mp}}$, of each string is $1.461 \mathrm{~A}$, and the maximum power point, $P_{\text {mp }}$, of each string is $180.78 \mathrm{~W}$. Fig. 4 shows the experimental results of $\mathrm{P}-\mathrm{V}$ curve under the condition that two strings are un-shaded. It can be that $P_{\mathrm{mp}}$ of solar cell array is $360 \mathrm{~W}$.
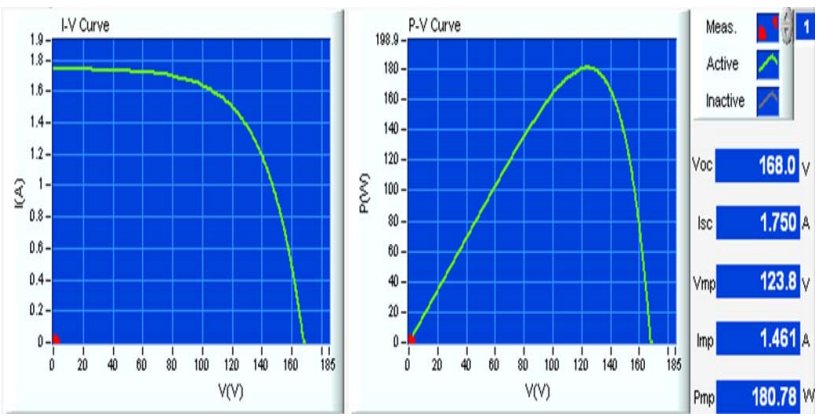

(a)
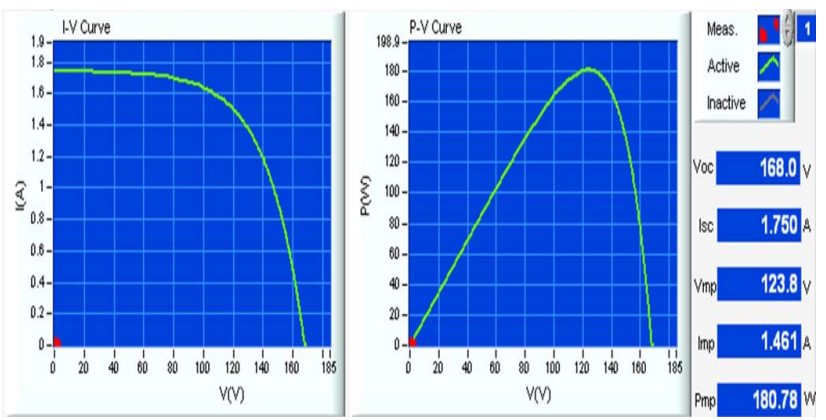

(b)

Figure 3. I-V and P-V curves for string 1 and string 2 of the solar simulators, (a) string 1, (b) string 2.

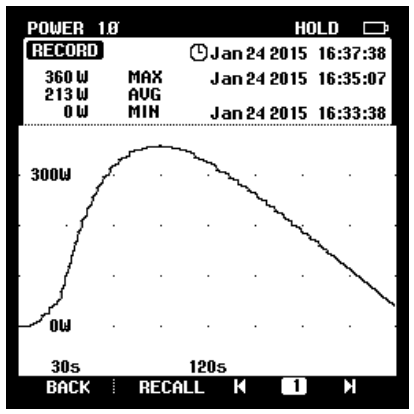

Figure 4. P-V curve of case 1.

\section{B. Case 2}

Fig. 5 to 6 show the experimental results under the condition that one solar module of the string 1 is shaded. The irradiance and the temperature of the back panel of unshadowed module are the same as case 1 . The irradiance of the shaded solar module is $300 \mathrm{~W} / \mathrm{m}^{2}$, and the temperature of its back panel is $30^{\circ} \mathrm{C}$. Fig. 5 shows the I-V and P-V curves of string 1 with one shaded solar module. As seen in Fig. 5, $V_{\text {oc }}$ is $162.9, I_{\mathrm{sc}}$ is $1.75 \mathrm{~A}, V_{\mathrm{mp}}$ is $92.8 \mathrm{~V}, I_{\mathrm{mp}}$ is $1.461 \mathrm{~A}$, and $P_{\mathrm{mp}}$ is $135.69 \mathrm{~W}$. Fig. 6 shows the P-V curve of case 2 before and after compensation. As can be seen in Fig. 6(a), the P-V curve has two peak points and $P_{\mathrm{mp}}$ before compensation is $291 \mathrm{~W}$. The $\mathrm{P}-\mathrm{V}$ curve after compensation is smooth and only one maximum power point. $P_{\mathrm{mp}}$ is $306 \mathrm{~W}$. 
Therefore, the output power of solar cell array at this case is increased after using a VC.

\section{Case 3}

Fig. 7 to 8 show the experimental results under one solar module of string 1 is shaded. The irradiance and the temperature of the back panel of un-shaded module are the same as case 1 . The irradiance of shaded solar module is $100 \mathrm{~W} / \mathrm{m}^{2}$, and the temperature of its back panel is $30^{\circ} \mathrm{C}$. Fig. 7 shows the I-V and P-V curves of case 3. As seen in Fig. 7, $V_{\text {oc }}$ is $155.8, I_{\mathrm{sc}}$ is $1.75 \mathrm{~A}, V_{\mathrm{mp}}$ is $92.8 \mathrm{~V}, I_{\mathrm{mp}}$ is $1.461 \mathrm{~A}$, and $P_{\mathrm{mp}}$ is $135.69 \mathrm{~W}$. Fig. 8 shows the P-V curve of case 3 before and after compensation. As can be seen in Fig. 8(a), the P-V curve has two peak points and $P_{\mathrm{mp}}$ before compensation is $297 \mathrm{~W}$. The P-V curve after compensation is smooth and only one maximum power point. $P_{\mathrm{mp}}$ is $309 \mathrm{~W}$. Therefore, the output power of solar cell array at this case is increased after using a VC.
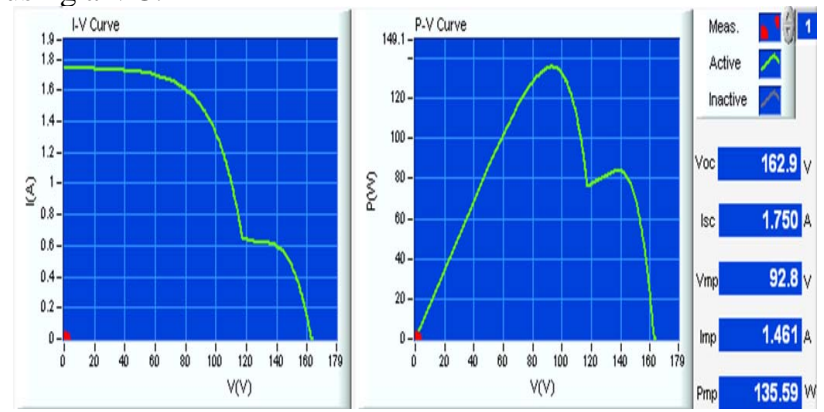

Figure 5. I-V and P-V curves of case 2.

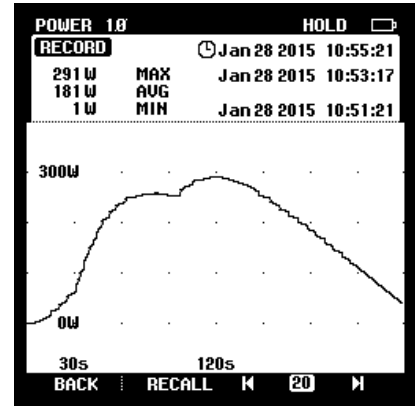

(a)

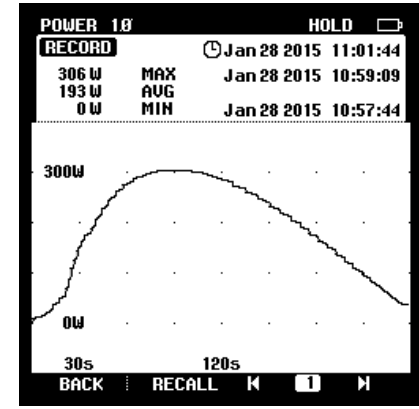

(b)
Figure 6. P-V curve of case 2, (a) before compensation, (b) after compensation.
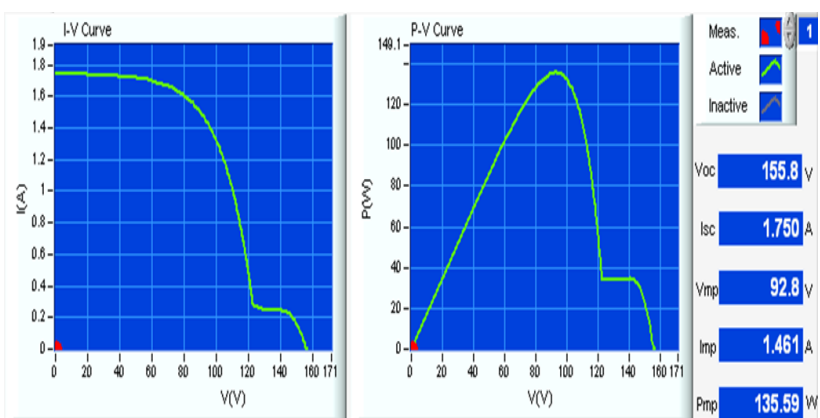

Figure 7. I-V and P-V curves of case 3.

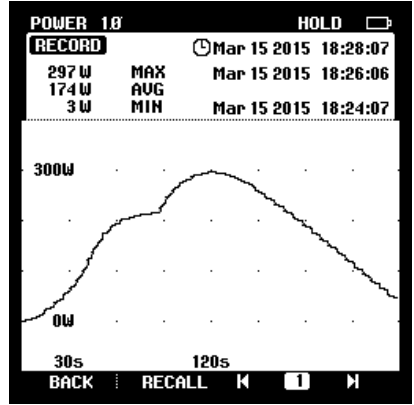

(a)

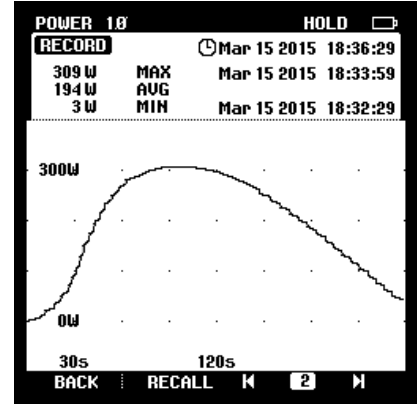

(b)
Figure 8. P-V curve of case 3, (a) before compensation, (b) after compensation.

\section{CONCLUSION}

A voltage compensator (VC) to compensate the shadowing phenomena of a solar generation system, including a solar cell array comprising several strings with the same maximum power point tracker, is proposed in this paper. The experimental results verify that the proposed VC can compensate for the voltage of shaded string to maintain the output voltages of every strings of a solar cell array to be almost the same. Therefore, the P-V curve after compensating is smooth and the problem of multi-peaks in $\mathrm{P}-\mathrm{V}$ curve of solar cell array caused by shadowing can be solved. And then, the generated power of a solar generation system can be increased.

\section{ACKNOWLEDGMENT}

The authors would like to express their acknowledgement to Ministry of Science and Technology, Taiwan for the financial support of this paper under the contract MOST-103-2815-C-151-018-E.

\section{REFERENCES}

[1] Karatepe E., Hiyama T., Boztepe M., and Colak M., "Power controller design for photovoltaic generation system under partially shaded isolation conditions," in Proc. Int. Conf. Intelligent Systems Applications to Power Systems, Nov. 5-8, 2007, pp. 1-6.

[2] Bangyin Liu, Chaohui Liang, and Shanxu Duan, "Design considerations and topology selection for dc-module-based building integrated photovoltaic system,” in Proc. IEEE Conf. Ind. Electron. Appl., Jun. 3-5, 2008, pp. 1066-1070.

[3] H. Patel and V. Agarwal, "MATLAB-based modeling to study the effects of partial shading on PV array characteristics," IEEE Trans. Energy Convers., Vol. 23, Issue 1, pp.302-310, Mar. 2008.

[4] Kadri R., Gaubert J.-P., and Champenois G., "Nondissipative string current diverter for solving the cascaded dc-dc converter connection problem in photovoltaic power generation system," IEEE Trans. Power Electron., Vol. 27, Issue 3, pp.1249-1258, Mar. 2012.

[5] AnssiM"aki and SeppoValkealahti, "Power losses in long string and parallel-connected short strings of series-connected silicon-based photovoltaic modules due to partial shading conditions," IEEE Trans. Energy Convers., Vol. 27, Issue 1, pp.173-183, Mar. 2012.

[6] D. L. King, W. E. Boyson and J. A. Kratochvil, "Photovoltaic array performance model," Sandia National Laboratories, P. O. Box 5800 Albuquerque, New Mexico 87185-0752, December. 2004. 
[7] D. King, J. Kratochvil, and W. Boyson, “Temperature coefficients for PV modules and arrays: measurement methods, difficulties, and results,” 26th IEEE PV Specialists Conference, 1997, pp. 1183-1186.

[8] D. King and P. Eckert, "Characterizing (rating) performance of large PV arrays for all operating conditions,” 25th IEEE PV Specialists Conference, 1996, pp. 1385-1388.

[9] D. L. King, G. M. Galbraith, W. E. Boyson, S. Gonzalez, A. T. Murray, J. W. Ginn and W. I. Bower, "Array performance characterization and modelingfor real-time performance analysis of photovoltaic systems," IEEE $4^{\text {th }}$ world Conference on Photovoltaic Energy Conversion, vol.2, no.,pp.2308-2311, May 2006

[10] K. H. Hussein, I. Muta, T. Hoshino, M. Osakada, "Maximum photovoltaic power tracking: an algorithm for rapidly changing atmospheric conditions”, IEE Proc. Gener. Trasnm. Distrib., Vol. 142 No. I, Jan. 1995

[11] P. Midya, P. T. Krein, R. J. Turnbull, R. Reppa, J. Kimball, "Dynamic maximum power point tracker for photovoltaic applications”, Proc. PESC, Baveno, Italy, 24- 27 June 1996, pp. 17101716.

[12] Brambilla A., Gambarara M., Garutti A., Ronchi F.: "New approach to photovoltaic arrays maximum power point tracking".Power Electronics Specialists Conference, 1999. PESC 99. 30th Annual IEEE Volume 2, 27 June-I July 1999 Pages: 632 - 637 vol.2

[13] D. Sera, T. Kerekes R. Teodorescu, F. Blaabjerg, "Improved MPPT algorithms for rapidly changing environmental conditions,“ Proc. of the 12th international power electronics and Motion control Conference, 1614-1619, 2006

[14] Young-Hyok Ji, Doo-Yong Jung, Chung-Yuen Won, Byoung-Kuk Lee, and Jin-Wook Kim, "Maximum power point tracking method for PV array under partially shaded condition,”in Proc. IEEE ECCE., Sep 20-24, 2009, pp. 307-312.

[15] H. Patel, and V. Agarwal,"Maximum power point tracking scheme for PV systems operating under partially shaded conditions,” IEEE Trans. On Power Electronics, Vol. 55, Issue 4, pp. 1689-1698, April 2008.

[16] Y. Nimni, D. Shmilovitz, “A return energy architecture for improved photovoltaic systems efficiency,” in Proc. IEEE ISCAS, May 2010, pp.2191-2194.

[17] T. Shimizu, M. Hirakata, T. Kamezawa, and H. Watanabe, "Generation control circuit for photovoltaic modules," IEEE Trans. Power Electron., vol. 16, no. 3, pp. 293-300, May 2001.

[18] R. Giral, C. A. Ramos-Paja, D. Gonzalez, J. Calvente, A. Cid-Pastor, and L. Martinez-Salamero, "Minimizing the effects of shadowing in a PV module by means of active voltage sharing," in Proc. IEEE ICIT, Mar. 14-17, 2010, pp. 943-948.

[19] Cheng-Huan Chung, Hurng-Liahng Jou, Kuen-Der Wu, and JinnChang Wu, "Shadowing compensator for grid-connected photovoltaic generation system,” in Proc. IEEE 9th ICIEA., June 9-11, 2014. 